American Journal of Applied Sciences 6 (1): 182-186, 2009

ISSN 1546-9239

(C) 2009 Science Publications

\title{
Studies on Biomass Production in Auricularia polytricha Collected from Wilberforce Island, Bayelsa State, Nigeria
}

\author{
${ }^{1}$ S.G. Jonathan, ${ }^{2}$ D.D.S. Bawo, ${ }^{1}$ D.O. Adejoye and ${ }^{2}$ O.F. Briyai \\ ${ }^{1}$ Department of Botany and Microbiology, University of Ibadan, Ibadan Nigeria \\ ${ }^{2}$ Department of Biological Sciences, Niger Delta University, \\ Wilberforce Island,Bayelsa State, Nigeria
}

\begin{abstract}
Auricularia polytricha (Mont) Saccardo, were found growing on decaying logs of wood in their large numbers within the marshy riverine ecosystem area of Wilberforce Island, Bayelsa State, Nigeria. The sporophores of this edible mushroom were tissue cultured and biomass production in submerged liquid medium was assessed. This fungus produced best mycelial biomass $\left(340 \mathrm{mg} \mathrm{cm}^{-3}\right)$ at $25^{\circ} \mathrm{C}$ after 15 days of incubation while no biomass was produced at 5,45 and $50^{\circ} \mathrm{C}$ after 20 days. Likewise, very good biomass was produced at $\mathrm{pH} 6.5$ after 10 days of incubation. Among the carbohydrate sources tested, glucose stimulated highest biomass yield of $375 \mathrm{mg} \mathrm{cm}^{-3}$ at $1.6 \%$ concentration closely followed by fructose $\left(350 \mathrm{mg} \mathrm{cm}^{-3}\right)$ at $1.8 \%$ concentration. All the nitrogen compounds investigated enhanced significant biomass production $(\mathrm{p} \leq 0.05)$. However, $0.8 \%$ of peptone stimulated the best biomass yield $\left(320 \mathrm{mg} \mathrm{cm}^{-3}\right)$ followed by tryptophan $\left(300 \mathrm{mg} \mathrm{cm}^{-3}\right)$ at $0.9 \%$ concentration. The volume of inoculum of A. polytricha that produced highest biomass of this fungus in liquid culture was $7.0 \mathrm{~cm}^{3}$. The implications of these findings were discussed.
\end{abstract}

Keywords: Biomass, Auricularia polytricha, Wilberforce Island, collection, submerged culture

\section{INTRODUCTION}

Previous work have been carried out on collection, identification and isolation of indigenous Nigerian mushrooms ${ }^{[1,2,3,4,5]}$.Investigations were carried out on these fungi basically, to determine their nutritional requirements and utilization in biotechnological processes. These organisms have been implicated in lignin and other recalcitrant substances degradation, soil bioremediation, production of edible biomass and secondary metabolites ${ }^{[6,7,8,9]}$. Auricularia polytricha is widely distributed throughout the tropical and subtropical regions of the world ${ }^{[10,27]}$. It belongs to phyllum basidiomycota, order auriculariales and family auriculariaceae ${ }^{[11]}$. This edible mushroom species is the commonest among the jelly-like fungi in West Africa. It grows wildly during the rainy season within the bark of a decaying wood under shade ${ }^{[3,10,11]}$. The sporophores of this fungus are usually found in their large numbers during late July.

Auricularia polytricha has a very peculiar consistency. The basidiocarp when fresh is rubbery, gelatinous and ear-like in structure but when dried, it is shapeless and brittle. Its edible fruitbodies could be easily identified by pilose upper surface which is strongly capitate with dark brown smooth hymenium $^{[3,10]}$. Fungal biomass have been found to be important for several purposes (i) It could be of immense advantage for process reduction in fermentation technology ${ }^{[12]}$ (ii) Fungal biomass could be used as food or protein supplement ${ }^{[13]}$ (iii) Fungal biomass could be used for flavour extraction ${ }^{[14]}$.(iv) They could be used for extraction of metabolites such as polysaccharides and enzymes ${ }^{[15]}$ (v) They could also be used for wound treatment ${ }^{[16]}$.

The primary objective of the present studies is therefore to culture $A$. polytricha in sub-merged liquid medium under different physico-chemical parameters with the aim of producing high yield biomass of this fungus.

\section{MATERIALS AND METHODS}

Micro-organism: Auricularia polytricha (Mont) Saccardo were found growing on logs of decaying wood in their large numbers within the marshy riverine ecosystem in Amassoma, Wilberforce Island, Bayelsa State, Nigeria. The sporophores of this fungus were tissue cultured and the mycelia culture thus obtained were maintained on Malt extract agar (Difco) ${ }^{[2,17]}$. 
Effect of incubation temperature on biomass production: The effect of incubation temperature on biomass production in A. polytricha was determined in a chemically defined medium. This medium has the following compositions $\left(\mathrm{g} \mathrm{L}^{-1}\right)$ glucose 10.0 , yeast extract $3.0, \mathrm{~K}_{2} \mathrm{HPO}_{4} \quad 0.6, \mathrm{MgSO}_{4} .7 \mathrm{H}_{2} \mathrm{O} \quad 0.3,1 \mathrm{~L}$ of distilled water and $\mathrm{pH}$ of $6.20^{[17]}$. The basal medium was dispensed into $250 \mathrm{~cm}^{3}$ conical flasks $\left(100 \mathrm{~cm}^{3}\right.$ per flask). Each was covered with aluminum foil and sterilized in the autoclave at $1.02 \mathrm{~kg} \mathrm{~cm}^{-2}$ at $121^{\circ} \mathrm{C}$ for $15 \mathrm{~min}$. After cooling, each flask was inoculated with vigorously growing (5 day old fungus) mycelial disc (7.0 mm diameter) acid incubated at 5, 10, 15, 20, 25, $30,35,40,45$ and $50^{\circ} \mathrm{C}$ respectively for $5,10,15$ and 20 days. Each treatment was replicated three times. The mycelial biomass produced were harvested using the method of Gbolagade et $a l^{[4]}$.

Effect of pH on biomass production in A. polytricha: For $\mathrm{pH}$, the same basal medium used for temperature determination was employed. The medium $\mathrm{pH}$ was adjusted to $4.0,4.5,5.0,5.5,6.0,6.5,7.0,7.5,8.0,8.5$ and $9.5 .100 \mathrm{~cm}^{3}$ of each treatment was dispensed into $250 \mathrm{~cm}^{3}$ conical flasks and replicated thrice. They were autoclaved at $121^{\circ} \mathrm{C}$ and $1.02 \mathrm{~kg} \mathrm{~cm}^{-2}$ for $15 \mathrm{~min}$. After cooling, they were inoculated and biomass produced were harvested as described in the temperature experiment.

Utilization of different concentration of carbon compounds for biomass production in A. polytricha: Four carbon sources namely glucose, fructose, mannitol and cellulose were evaluated. The concentration of these carbohydrate compounds used varies between $0.2-2.0 \%$ while the basal medium that lack any carbon compound $(0 \%)$ served as the control. The fermentation medium has the following compositions in percentage (\%): peptone $0.2, \mathrm{MgSO}_{4} \cdot 7 \mathrm{H}_{2} \mathrm{O} 0.1, \mathrm{~K}_{2} \mathrm{H} \mathrm{PO}_{4} \cdot 3 \mathrm{H}_{2} \mathrm{O}$ 0.1 and $1000 \mathrm{~cm}^{3}$ of distilled water ${ }^{[18]}$. Each concentration of these carbon compounds was supplemented in the basal medium and the experiment were replicated three times.

Utilization of different concentration of nitrogen compounds for biomass production in A. polytricha: Four different sources of organic and inorganic nitrogen sources were used. These were alanine, tryptophan, ammonium sulphate and peptone. Fermentation medium was similar to the one of carbon sources but the nitrogen sources were replaced at an equivalent concentration. Various concentration of nitrogen compounds supplemented in this medium ranges from 0.01-0.12 (Table 4).
Effect of inoculum sizes on biomass production in $\boldsymbol{A}$. polytricha: The basal medium used was that described by Maziero et al. (1999). It has the following composition $\left(\mathrm{g} \mathrm{L}^{-1}\right)$ peptone 1.0 yeast extract 2.0, $\mathrm{K}_{2} \mathrm{HPO}_{4} \quad 1.0, \mathrm{MgSO}_{4} .7 \quad \mathrm{H}_{2} \mathrm{O} \quad 0.2,\left(\mathrm{NH}_{4}\right)_{2} \mathrm{SO}_{4} \quad 5.0$, glucose 39.0 and $1000 \mathrm{~cm}^{3}$ of distilled water, the medium was adjusted to $\mathrm{pH}$ 6.5. To generate enough inoculum, A. polytricha was initially inoculated onto the above medium for 6 days $^{[2]}$. Thereafter, different concentrations of this fungus $\left(0.5-10.0 \mathrm{~cm}^{3}\right)$ (Table 5), were then aseptically inoculated into $250 \mathrm{~cm}^{3}$ conical flasks containing $100 \mathrm{~cm}^{3}$ of the chemically defined liquid medium. Each treatment has 3 replicates .Incubation was carried out for 10 days at room temperature $30 \pm 2^{\circ} \mathrm{C}$ after which mycelia were harvested as described in the previous experiment.

Analysis of data: Rating results in each treatment of triplicate experiments were subjected to analysis of variance (ANOVA) using general linear model option SAS. Test of significance were determined by Duncan's multiple range test at $0.5 \%$ level of probability.

\section{RESULTS AND DISCUSSION}

Table 1 shows that $A$. polytricha could produced mycelial biomass within the temperature range of 10 and $40^{\circ} \mathrm{C}$. The best biomass yield was obtained at $25^{\circ} \mathrm{C}$ after 15 days of incubation. It could be seen clearly that the minimum, optimum and maximum temperatures for biomass production of this fungus were 10, 25 and $40^{\circ} \mathrm{C}$ respectively. It was also observed that no biomass was produced at 5,45 and $50^{\circ} \mathrm{C}$. Biomass production of this fungus was not favoured by extremely cold nor high temperatures $\left(5,45\right.$ and $\left.50^{\circ} \mathrm{C}\right)$. Similar observations were made by Gbolagade et al. ${ }^{[4]}$ for

Table 1: Effect of Incubation temperature on biomass production in A. polytricha

\begin{tabular}{lllll}
\multicolumn{5}{c}{ A. polytricha } \\
$\begin{array}{l}\text { Day } \\
\text { Temp }\left({ }^{\circ} \mathrm{C}\right)\end{array}$ & 5 & 10 & 15 & 20 \\
\hline 5 & - & - & - & - \\
10 & - & $30 \mathrm{e}$ & $40 \mathrm{e}$ & $40 \mathrm{ef}$ \\
15 & $20 \mathrm{~d}$ & $70 \mathrm{~d}$ & $40 \mathrm{e}$ & $30 \mathrm{f}$ \\
20 & $40 \mathrm{~cd}$ & $120 \mathrm{c}$ & $70 \mathrm{~d}$ & $55 \mathrm{de}$ \\
25 & $90 \mathrm{a}$ & $295 \mathrm{a}$ & $340 \mathrm{a}$ & $270 \mathrm{a}$ \\
30 & $65 \mathrm{~b}$ & $260 \mathrm{~b}$ & $300 \mathrm{~b}$ & $240 \mathrm{~b}$ \\
35 & $30 \mathrm{de}$ & $120 \mathrm{c}$ & $125 \mathrm{c}$ & $90 \mathrm{c}$ \\
40 & $10 \mathrm{e}$ & $20 \mathrm{f}$ & $20 \mathrm{f}$ & $20 \mathrm{~g}$ \\
45 & - & - & - & - \\
50 & - & - & - & - \\
\hline Data represented above are means of 3 replicates. Values followed by \\
the same letter(s )along each vertical column are not significantly \\
different by Duncan's multiple range test (p $\leq 0.05)$
\end{tabular}


Am. J. Applied Sci., 6 (1): 182-186, 2009

Table 2: Effect of $\mathrm{pH}$ on biomass production in A. polytricha

\begin{tabular}{|c|c|c|c|c|}
\hline \multirow{2}{*}{$\begin{array}{l}\mathrm{pH} \\
\text { Day }\end{array}$} & \multicolumn{4}{|c|}{ Biomass production $\left(\mathrm{mg} 100 \mathrm{~cm}^{-3}\right.$ ) } \\
\hline & 5 & 10 & 15 & 20 \\
\hline 4.0 & - & - & - & - \\
\hline 4.5 & $30 \mathrm{~g}$ & $30 \mathrm{e}$ & $50 \mathrm{~h}$ & $40 \mathrm{gh}$ \\
\hline 5.0 & $65 \mathrm{f}$ & $120 \mathrm{~d}$ & $100 \mathrm{fg}$ & $50 \mathrm{fg}$ \\
\hline 5.5 & $90 \mathrm{e}$ & $190 \mathrm{c}$ & $150 \mathrm{e}$ & $90 \mathrm{de}$ \\
\hline 6.0 & $145 b$ & $265 b$ & $200 \mathrm{~d}$ & $150 \mathrm{c}$ \\
\hline 6.5 & $190 \mathrm{a}$ & $310 \mathrm{a}$ & $240 \mathrm{~b}$ & $165 b c$ \\
\hline 7.0 & $120 \mathrm{c}$ & $260 \mathrm{~b}$ & $270 \mathrm{a}$ & $190 \mathrm{a}$ \\
\hline 7.5 & $100 \mathrm{dc}$ & $205 \mathrm{c}$ & $220 \mathrm{c}$ & $150 \mathrm{c}$ \\
\hline 8.0 & $70 f$ & $130 \mathrm{~d}$ & $90 \mathrm{~g}$ & $75 \mathrm{e}$ \\
\hline 8.5 & $20 \mathrm{~g}$ & $40 \mathrm{e}$ & $50 \mathrm{~h}$ & $30 \mathrm{~h}$ \\
\hline 9.0 & - & - & - & - \\
\hline
\end{tabular}

Data represented above are means of 3 replicates. Values followed by the same letter along each vertical column are not significantly different by Duncan's multiple range test $(\mathrm{p} \leq 0.05)$

Pleurotus florida. Maziero et al. ${ }^{[12]}$ also observed that the best biomass yields were obtained between temperature range of 25 and $30^{\circ} \mathrm{C}$.

It was observed from Table 2 that $A$. polytricha produced best biomass $\left(310 \mathrm{mg} / 100 \mathrm{~cm}^{3}\right)$ at $\mathrm{pH} 6.5$ after 10 days of incubation. The least mycelial biomass $\left(20.0 \mathrm{~g} / 100 \mathrm{~cm}^{3}\right)$ was obtained after 5 days of culturing while no biomass was produced at $\mathrm{pH} 4.0$ and 9.0 respectively. Biomass yield on the 5th day was generally lower than that of the 10,15 and 20 days. The reason for this may be due to the fact that on the 5th day, the fungal mycelia have not fully recovered from the logarithm phase. During this phase, there may be no obvious sign of metabolism and development. Microorganisms generally start to generate energy for anabolism, growth and biomass production ${ }^{[19]}$. At the 10th day, the fungus was experiencing exponential phase. This is the period of active metabolism, growth, development and optimal biomass production by this fungus ${ }^{[19]}$. On the 15th and 20th day, it was undergoing declining phase. This may be the reason why low biomass yields were generally observed after 15 th and 20th day. These results were similar to that of Chandra and Purkayastha ${ }^{[20]}$ on Agaricus compestis. Excellent mycelial biomass yield were also obtained by Jonathan and $\mathrm{Fasidi}^{[21]}$ on Psathyrella atroumbonata at $\mathrm{pH}$ 6.5.

Table 3 demonstrates the effects of carbon compounds for mycelial biomass production. Glucose, a monosaccharide at the concentration of $1.6 \%$ produced the best biomass yield $\left(375.0 \mathrm{mg} / \mathrm{cm}^{3}\right)$. Also, it was observed that monosaccharides in general were better than sugar alcohol and complex sugar (cellulose) for biomass production. This was probably due to ease in polymerization and their simple nature ${ }^{[17]}$. These observations in regard to A. polytricha seemed to be important because only little is known on the utilization of carbon compounds for biomass production in
Table 3: Utilization of different concentrations of carbon compounds for biomass production in A. polytricha

\begin{tabular}{|c|c|c|c|c|}
\hline \multirow{2}{*}{$\begin{array}{l}\text { Carbon compounds } \\
\text { concentration }(\%)\end{array}$} & \multicolumn{4}{|c|}{ Biomass production $\left(\mathrm{mg} 100 \mathrm{~cm}^{-3}\right.$ ) } \\
\hline & glucose 5 & fructose 10 & mannitol & 5 cellulose 20 \\
\hline$\overline{0 \%}$ & $25 \mathrm{j}$ & $25 \mathrm{k}$ & $25 \mathrm{j}$ & $25 \mathrm{k}$ \\
\hline $0.2 \%$ & $50 \mathrm{i}$ & $35 \mathrm{jk}$ & $45 i$ & $50 \mathrm{ij}$ \\
\hline $0.4 \%$ & $75 \mathrm{~h}$ & $60 \mathrm{i}$ & $80 \mathrm{~g}$ & $65 \mathrm{gh}$ \\
\hline $0.6 \%$ & $110 \mathrm{~g}$ & 70hi & $85 \mathrm{fg}$ & $70 \mathrm{fg}$ \\
\hline $0.8 \%$ & $170 \mathrm{f}$ & $95 \mathrm{~g}$ & $110 \mathrm{de}$ & $90 \mathrm{de}$ \\
\hline $1.0 \%$ & $205 \mathrm{e}$ & $120 \mathrm{f}$ & $180 \mathrm{bc}$ & $175 a$ \\
\hline $1.2 \%$ & $270 \mathrm{~d}$ & $155 \mathrm{c}$ & $215 a$ & $140 \mathrm{~b}$ \\
\hline $1.4 \%$ & $340 \mathrm{~b}$ & $200 d$ & $170 \mathrm{c}$ & $100 \mathrm{c}$ \\
\hline $1.6 \%$ & $375 a$ & $290 b c$ & $100 \mathrm{e}$ & $85 \mathrm{ef}$ \\
\hline $1.8 \%$ & $305 c$ & $350 \mathrm{a}$ & $75 \mathrm{~g}$ & $60 \mathrm{hi}$ \\
\hline $2.0 \%$ & $210 \mathrm{e}$ & $280 \mathrm{c}$ & $55 \mathrm{hi}$ & $40 \mathrm{j}$ \\
\hline
\end{tabular}

Data represented above are means of 3 replicates. Values followed by the same letter along each vertical column are not significantly different by Duncan's multiple range test $(\mathrm{p} \leq 0.05)$

Table 4: Utilization of different concentrations of nitrogen compounds for biomass production in A. polytricha

\begin{tabular}{lcccc}
\hline & \multicolumn{4}{c}{ Biomass production $\left(\mathrm{mg} / 100 \mathrm{~cm}^{3}\right)$} \\
$\mathrm{N}_{2}$ Compounds & -------------- & \\
Concentration in \% & Alanine & Tryptophan & $\left(\mathrm{NH}_{4}\right)_{2} \mathrm{SO}_{4}$ & Peptone \\
\hline 0 & $20 \mathrm{~h}$ & $20 \mathrm{k}$ & $20 \mathrm{~h}$ & $20 \mathrm{k}$ \\
0.01 & $70 \mathrm{f}$ & $40 \mathrm{j}$ & $50 \mathrm{ef}$ & $30 \mathrm{jk}$ \\
0.02 & $100 \mathrm{e}$ & $60 \mathrm{ij}$ & $50 \mathrm{ef}$ & $40 \mathrm{ij}$ \\
0.03 & $150 \mathrm{~d}$ & $75 \mathrm{hi}$ & $120 \mathrm{ab}$ & $70 \mathrm{~h}$ \\
0.04 & $190 \mathrm{bc}$ & $95 \mathrm{~g}$ & $110 \mathrm{~b}$ & $100 \mathrm{~g}$ \\
0.05 & $230 \mathrm{a}$ & $120 \mathrm{f}$ & $90 \mathrm{~cd}$ & $160 \mathrm{f}$ \\
0.06 & $180 \mathrm{c}$ & $170 \mathrm{e}$ & $75 \mathrm{~d}$ & $210 \mathrm{~d}$ \\
0.07 & $155 \mathrm{~d}$ & $240 \mathrm{~d}$ & $70 \mathrm{~d}$ & $275 \mathrm{c}$ \\
0.08 & $115 \mathrm{e}$ & $290 \mathrm{bc}$ & $45 \mathrm{f}$ & $320 \mathrm{a}$ \\
0.09 & $70 \mathrm{f}$ & $285 \mathrm{ab}$ & $40 \mathrm{fg}$ & $290 \mathrm{bc}$ \\
0.10 & $50 \mathrm{~g}$ & $300 \mathrm{a}$ & $30 \mathrm{gh}$ & $210 \mathrm{~d}$ \\
0.12 & $50 \mathrm{~g}$ & $250 \mathrm{de}$ & $30 \mathrm{gh}$ & $185 \mathrm{ef}$ \\
\hline
\end{tabular}

Values followed by the same letter(s) along each column are not significantly different by Duncan's multiple range. Data are means of 3 replicates

A. polytricha. The little amount of biomass with cellulose may be attributed to its complex nature. Sugar alcohol and polysaccharides will be hydrolyzed to monosaccharide before they will enter respiratory pathways $^{[22]}$.

All the 4 nitrogen compounds used in this investigation significantly promoted biomass yield. (Table 4). The most stimulatory nitrogen compound was peptone at $0.08 \%$ concentration. This result is contrary to that obtained by Gbolagade et al. ${ }^{[4]}$ on Pleurotus florida. These workers obtained better biomass yield in ammonium nitrate better than peptone. The differences in nitrogen sources requirements may suggest that biomass production in different fungi may be influenced by different nutritional requirements. It was also observed that very low concentration of nitrogen compounds (0.01-0.03\%) generally supported little biomass yield while low concentration $0.4 \%$ and above were supportive to high biomass yield ${ }^{[23]}$. The 
Am. J. Applied Sci., 6 (1): 182-186, 2009

Table 5: Effect of inoculum sizes on biomass production in

\begin{tabular}{lll}
\multicolumn{2}{c}{ A. polytricha } & \\
\hline Volume of & Biomass yield $\mathrm{mg}$ & \\
inoculum $\left(\mathrm{cm}^{3}\right)$ & $100 \mathrm{~cm}^{-3}$ & Mycelial density \\
\hline 0.5 & $25 \mathrm{j}$ & +2 \\
1.0 & $40 \mathrm{ij}$ & +3 \\
2.0 & $65 \mathrm{~h}$ & +4 \\
3.0 & $85 \mathrm{~g}$ & +4 \\
4.0 & $110 \mathrm{f}$ & +7 \\
5.0 & $120 \mathrm{ef}$ & +7 \\
6.0 & $175 \mathrm{c}$ & +8 \\
7.0 & $260 \mathrm{a}$ & +9 \\
8.0 & $200 \mathrm{~b}$ & +7 \\
9.0 & $180 \mathrm{c}$ & +5 \\
10.0 & $150 \mathrm{~d}$ & +4 \\
\hline
\end{tabular}

Values followed by the same letters(s) along each column are not significantly different by Duncan's multiple range test $(\mathrm{p} \leq 0.05)$. Data are means of 3 replicates

best yield $\left(320 \mathrm{mg} / 100 \mathrm{~cm}^{3}\right)$ was obtained with peptone. Similar utilization of peptone by basidiomycetes has been reported ${ }^{[24]}$. The supportive action of peptone on biomass production in $A$. polytricha may be linked to its carbohydrate, amino acids and vitamin composition.

The effect of inoculum sizes on biomass production is presented on Table 5. It was observed that all the volume of inoculum used (0.5-10.0) produced varying degrees of biomass yield. The best mycelial biomass was obtained at $7.0 \mathrm{~cm}^{3}$ (i.e., $260 \mathrm{mg}$ $100 \mathrm{~cm}^{-3}$ ). This result is similar to that obtained by Jonathan et al. ${ }^{[25]}$ for L. subnudus. Rew et al. ${ }^{[26]}$ reported that the inoculum sizes may determine biomass production in an agitated system.

\section{REFERENCES}

1. Fasidi, I.O., 1996. Growth requirements of Volvariella speciosa (Fr. Ex. Fr.) Sing, a Nigerian mushroom. Food Chem., 55 (2): 165-168.

2. Jonathan. S.G. and I.O. Fasidi, 2001. Effect of carbon, nitrogen and mineral sources on growth of Psathyrella antroumbonata (Peyler), a Nigerian edible mushroom. Food Chem., 72: 479-783

3. Jonathan, S.G., 2002. Vegetative growth requirements and antimicrobial activities of some higher fungi in Nigeria. Ph.D Thesis, University of Ibadan, Ibadan, pp: 268.

4. Gbolagade, J., A. Sobowale and D. Adejoye, 2006. Optimization of sub-merged culture conditions biomass production in Pleurotus florida (Mont) Singer), a Nigerian fungus. Afr. J. Biotech., 5 (16): 1464-1469.

5. Fasola, T.R. J.S. Gbolagade and I.O. Fasidi, 2007. Nutritional requirements of Volvariella speciosa (Fr. Ex. Fr) Singer, a Nigerian Edible Mushroom. Food Chem., 100: 904-908.
6. Adenipekun, C.O. and I.O. Fasidi, 2005. Bioremediation of oil-polluted soil by Lentinus subnudus, a Nigerian white-rot fungus. Afr. J. Biotech., 4 (8): 796-798.

7. Jonathan, S.G., 2006. Effect of different nutrient sources on biomass production of Lepiota procera in sub merged liquid cultures. Afr. J. Biotech., 5 (12): 1246-1249.

8. Ray, B., 2006. Polysaccharides from Entermorpha compressa. Isolation, purification and structure features. Carbohydrate Polymers. 66: 408-416.

9. Hou, X. and W. Chen, 2007. Optimization of extraction process of crude polysaccharides from wild edible Bachu mushroom by response surface methodology. Carbohydrate Polymer (In Press).

10. Zoberi, 1972. Tropical Macrofungi. Macmillan Press London. pp: 158.

11. Bandoni, R.J., 1984. The Tremellales and Auriculariales, alternative classification. Trans. Mycol. Soc. Japan 25: 489-530.

12. Maziero, R. V. Cavasson, V. Luas and Bononia, 1999. Screening of basidiomyetes for production of exopolysaccharide and biomass production in submerged culture. Rev. de Microbiol., 30: 77-84.

13. Kadiri, 1990. Physiological studies on some Nigerian mushrooms. Ph.D Thesis, University of Ibadan, Ibadan, Nigeria.

14. Jong, S.C. and J.M. Birgmingham, 1993. In: Mushroom Biology and Mushroom Products. Chang, S.T., J.A. Buswell and W. Chius (Eds.). The Chinesse University Press, Hong Kong, pp: 345-366.

15. Sone, Y., R. Okuda, N. Wada E. Kishida and A. Misaki, 1985. Structures and antitumur activities of polysaccharides isolated from fruiting body and mycelium of Ganoderma lucidum. Agric. Biol. Chem., 49 (9): 2641-2693.

16. Hamlyn, P.F. and R.J. Schmidt, 1994. Potential therapeutic application of fungal filaments in wound management. Mycologia, 8: 147-152.

17. Leifa, F., T.S. Andra, P. Ashok and R.S. Carlos, 2007. Effect of nutritional and environmental conditions on production of exopolysaccharide of Agaricus brasiliensis by sub-merged fermentation and its antifumor activity. LWT J., 40: 30-35.

18. Li, P. and Zhang, 1999. Unstructured kinetic models for exo-polysaccharides production by batch fermentation of Ganoderma lucidum. Biotechnology, 9 (3): 8-14.

19. Griffin, D.H., 1994. Fungal Physiology. 2nd Edn. New York Wiley Ltd.

20. Chandra, A. and Purkayastha, 1977. Physiological studies on Indian edible mushrooms. Trans. Br. Mycol. Soc., 69: 63-70. 
21. Jonathan S.G. and I.O. Fasidi, 2003. Studies on Psathyrella atroumbonata (Pegler), a Nigerian edible fungus. Food Chem., 81: 481-484.

22. Mahier, H.R. and H.E. Cordes, 1971. Biological Chemistry. 2nd Edn. New York. Harper and Row.

23. Yajie T. and J.T. Zhong, 2002. Fed batch fermentation of Ganoderma lucidum for hyperproduction of polysaccharides and ganoderic acid. Enzyme Micr. Tech., 31: 20-28.

24. Fasidi, I.O. and S.G. Jonathan, 1994. Growth requirements of Volvariella esculenta (Mass) Singer, a Nigerian Edible Mushroom. Chem. Mrkrobiol. Tech. Lebensm., 16 (56): 151-155.
25. Jonathan, S.G., I.O. Fasidi, A.O. Ajayi and A. Adegeye, 2008. Biodegradation of Nigerian wood wastes by Pleurotus tuber-regium (Fries) Singer. Bioresour. Technol., 99 (4): 807-811.

26. Rew, Y.H.J.O.W.S., K.C. Jeong, J.T. Yoo and B.S. Choi, 2000. Cultural characteristics and fruit boding formation of Phellinuts qilvus. Kirech J. Mycol., 28: 610.

27. Well, K., 1984. The Jelly fungi then and now. Mycologia, 86: 18-48. 